\title{
ISOLATION OF TOXOPLASMA GONDII IN FREE-LIVING SMALL MAMMALS AND BIRDS
}

\author{
K. HEJLÍČKK, F. PROŠEK, F. TREML \\ Department of Epizootiology and Microbiology, University of Veterinary Science, 61242 Brno
}

Received May 7, 1980

\begin{abstract}
Hejlíček K., F. Prošek, F. Treml: Isolation of Toxoplasma gondii in Free-living Small Mammals and Birds. Acta vet. Brno, 50, 1981: 233-236.

In the period from March to December 1979, 72 specimens of free-living small mammals and birds were investigated by means of isolation experiments in Toxoplasma-negative white mice. The animals were caught in March, May, July, and November. $T$. gondii was isolated from their brains. In the respective months $T$. gondii was isolated in $21.7 \%, 10.5 \%, 18.7 \%$, and $18.6 \%$ of the animals. Of the total number of 72 animals the T. gondii isolation was positive in $19.4 \%$. The causative agent was found in the domestic sparrow (Passer domesticus), field sparrow (Passer montanus), yellowhammer (Emberiza citrinella), domestic mouse (Mus musculus, field mouse (Apodemus sylvaticus) in $17.5 \%, 25 \%, 20 \%, 60 \%$, and $20 \%$, resp. The agent was not proved in the redstart (Phoenicurus ochruros), white wagtail (Motacilla alba), house martin (Delichon urbica), serin (Serinus serinus), goldfinch (Carduelis carduelis).
\end{abstract}

Toxoplasma gondii, occurrence, natural focality.

Toxoplasmosis is a disease of protozoan etiology rather widely spread in the free nature. The small wild mammals are very important for the maintenance and distribution of the causative agent Toxoplasma gondii in nature (Jíra et al. 1965). It is supposed that the infection is maintained within these species through a permanent intrauterine transmission. Thus the small wild mammals become a reservoir of infection from which $T$. gondii can spread to other animal species. Istomina et al. (1973) in the USSR found Sorex araneus, Clethrionomys glareolus, Apodemus sylvaticus, Microtus arvalis, Apodemus flavicollis to be infested in $21 \%, 10 \%, 41 \%, 7.6 \%, 100 \%$, resp. In the USA Eyles et al. (1959) found that as many as $20 \%$ of the mammals living in the wild had antibodies to T. gondii. In Czechoslovakia, for example, Rosický et al. (1969) examined serologically 107 small mammals living in the wild and found these antibodies in $17 \%$ of the animals. Ca tár (1972) serologically examined 534 small mammals living in the wild and found toxoplasma antibodies in Apodemus flavicollis, Apodemus sylvaticus and Microtus arvalis in $6.4 \%, 3.8 \%$ and $5.8 \%$, resp. At the same time the author proved $T$. gondii cysts in two cases after microscopical examination, i. e. in Apodemus flavicollis and Microtus arvalis.

T. gondii occurs rather often also in free-living birds. Haslett and Schneider (1978), for example, serologically examined 563 samples of sera of the starling (Sturnus vulgaris) and proved antibodies in $4.8 \%$. In Czechoslovakia Catár (1974) found T. gondii antibodies in $40.9 \%$ birds living in the wild.

In the present study the authors aimed at isolation of $T$. gondii from animals living in the wild and caught in the surroundings of small herds of domestic animals studied. The aim was to verify the occurrence of the agent in the wild animals caught because the domestic animals kept in small herds are in intensive contact with the free nature and it can be anticipated that toxoplasmosis will spread from the wild animals also to these herds. 


\section{Materials and Methods}

In the period from March till December 1979 the small wild mammals and birds were caught in 4 intervals from the surroundings of small herds and they were subjected to long-term epizootiological examinations. In this period (from March till December 1979) 72 small animals living in the wild were caught, i. e. 23 in March, 19 in May, 16 in July, 14 in November. For the isolation of T. gondii in Toxoplasma-negative white mice the brains of the caught animals were employed. The sample was cut into a thick-walled beaker and $15 \mathrm{ml}$ of buffered saline with and addition of antibiotics (STM $1 \mathrm{~g}$, PNC $600000 \mathrm{I}$. U. per $1000 \mathrm{ml}$ of saline) was added. Homogenization was performed on a submersile eletric mixer with an exchangeable fitter. One $\mathrm{ml}$ of the suspension was applied intraperitoneally to white mice, strain ICR, weigh ing $35-40 \mathrm{~g}$, delivered as Toxoplasma - negative by the national enterprise Velaz, Prague - Lysolaje. The negativity was serologically confirmed in our labory in a selected specimen of mice delivered. From each specimen 3 mice were inoculated. The mice were constantly observed, after 5 weeks they were bled. From the brain of each infected mouse three compression microscopical preparations were prepared for the demonstration of $T$. gondii cysts. Mixed samples of blood sera of mice infected with one sample were tested serologically using the Sabin-Feldman reaction (SFR) and microprecipitation in agar gel (MPA). The SFR was performed according to the methods of the ÚSVÚ (Central State Institute for Veterinary Medicine) in Prague, MPA according to the official methods of the ÚSOL (Institute of Sera and Inoculation Substances).

\section{Results}

Caught and examined were 40 domestic sparrows (Passer domesticus), 5 yellowhammers (Emberiza citrinella), 4 field sparrows (Passer montanus), 4 redstarts (Phoenicurus ochruros), one white wagtail (Motacilla alba), one house martin (Delichon urbica), one serin (Serinus serinus), and one goldfinch (Carduelis carduelis). Of the wild mammals caught and examined were Apodemus sylvaticus (10 animals) and Mus musculus (5 animals). Results of the isolation are given in the Table.

Table 1

Results of isolation demonstration of $T$. gondii from small animals living in the wild

\begin{tabular}{|c|c|c|c|c|c|c|c|c|c|c|c|c|c|c|c|}
\hline \multirow{2}{*}{ Species } & \multicolumn{3}{|c|}{ March 15} & \multicolumn{3}{|c|}{ May 17} & \multicolumn{3}{|c|}{ July 18} & \multicolumn{3}{|c|}{ November 15} & \multicolumn{3}{|c|}{ Total } \\
\hline & $\underset{\text { ber }}{\text { num- }}$ & $\begin{array}{l}\text { pos. } \\
\text { isol. }\end{array}$ & $\%$ & $\mid \begin{array}{c}\text { num- } \\
\text { ber }\end{array}$ & $\begin{array}{l}\text { pos. } \\
\text { isol. }\end{array}$ & $\%$ & $\underset{\text { ber }}{\text { num- }}$ & $\begin{array}{l}\text { pos. } \\
\text { isol. }\end{array}$ & $\%$ & $\underset{\text { ber }}{\text { num- }}$ & $\begin{array}{l}\text { pos. } \\
\text { isol. }\end{array}$ & $\%$ & $\begin{array}{c}\text { num- } \\
\text { ber }\end{array}$ & $\begin{array}{l}\text { pos. } \\
\text { isol. }\end{array}$ & $\%$ \\
\hline $\begin{array}{l}\text { Passer domesticus } \\
\text { Emberiza citrinella } \\
\text { Passer montanus } \\
\text { Phoenicurus ochruros } \\
\text { Motacilla alba } \\
\text { Delichon urbica } \\
\text { Serinus serinus } \\
\text { Carduelis carduelis } \\
\text { Apodemus sylvaticus } \\
\text { Mus musculus }\end{array}$ & 20 & 3 & 66.7 & $\begin{array}{l}6 \\
5 \\
1 \\
3 \\
1 \\
1 \\
1 \\
1\end{array}$ & $\begin{array}{l}1 \\
1 \\
0 \\
0 \\
0 \\
0 \\
0 \\
0\end{array}$ & $\begin{array}{c}16.7 \\
20 \\
0 \\
0 \\
0 \\
0 \\
0 \\
0\end{array}$ & $\begin{array}{r}12 \\
1\end{array}$ & $\begin{array}{l}2 \\
0\end{array}$ & $\begin{array}{c}16.7 \\
0\end{array}$ & $\begin{array}{l}2 \\
3\end{array}$ & $\begin{array}{l}1 \\
1\end{array}$ & $\begin{array}{l}50 \\
33.3\end{array}$ & $\begin{array}{r}40 \\
5 \\
4 \\
4 \\
1 \\
1 \\
1 \\
1 \\
10 \\
5\end{array}$ & $\begin{array}{l}7 \\
1 \\
1 \\
0 \\
0 \\
0 \\
0 \\
0 \\
2 \\
3\end{array}$ & $\begin{array}{c}17.5 \\
20 \\
25 \\
0 \\
0 \\
0 \\
0 \\
0 \\
20 \\
60\end{array}$ \\
\hline TOTAL & 23 & 5 & 21.7 & 19 & 2 & 10.5 & 16 & 3 & 18.7 & 14 & 4 & 28.6 & 72 & 14 & 19.4 \\
\hline
\end{tabular}

As evident from the Table, the agent was isolated in $21.7 \%, 10.5 \%, 18.7 \%$ and $18.6 \%$ of the animals in March, May, July and November, resp. The isolation was positive in 7 domestic sparrows (Passer domesticus), in one of the yellowhammers (Emberiza citrinella), in one of the field sparrows (Passer montanus), i. e. $17.5 \%, 20 \%, 25 \%$, resp. The authors did not succeed in isolating the para. site from the redstart (Phoenicurus ochruros), white wagtail (Motacilla alba), house martin (Delichon urbica), serin (Serinus serinus), and goldfinch (Carduelis 
carduelis). In Apodemus sylvaticus the isolation was positive in 2 animals $(20 \%)$, in Mus musculus in $60 \%$. Of the total number of 72 animals examined for isolation and living in the wild $T$. gondii was isolated in 14 , i. e. $19.4 \%$.

\section{Discussion}

The present results of $T$. gondii isolation from birds and mammals living in the wild agree with the results of serological examinations performed

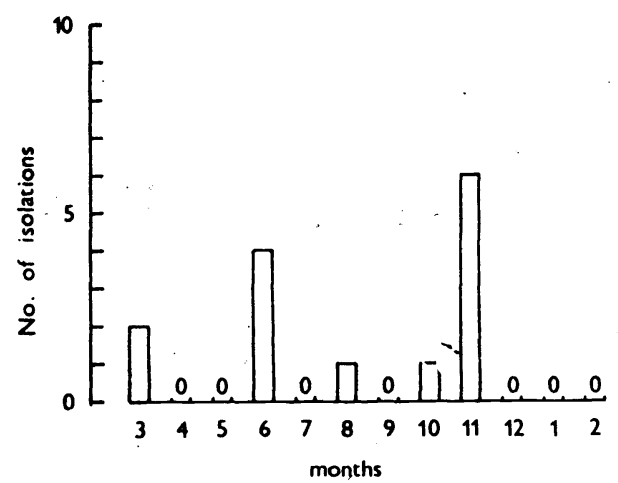
by other authors in that toxoplasmosis is a considerably widely spread disease in the free nature. Of the total number of animals examined T. gondii was isolated in $19.4 \%$. It was found most frequently in animals caught in March $(21.7 \%$ ) and November $(28.6 \%)$. The authors' results in this respect are similar to the findings of Haslett and Schneider (1978) who proved antibodies to $T$. gondii during the months of May till November in their serological examinations of starlings. Of the 8 species of wild birds the presence of T. gondii was proved in three. However, it is necessary to bear in mind that of the other five species examined were only a few. If more of these had been examined $T$. gondii isolation could have been anticipated also in these five species of wild birds. The results of the authors' examinations indicate that small wild animals are an important reservoir of toxoplasmosis in the nature from which the causative agent can spread to populations of domestic animals kept especially in small herds where there is a close contact with the nature.

\section{Izolační průkaz Toxoplasma gondii u drobných volně žijících savců a ptáků}

Izolačnimi pokusy na Toxoplazma-negativních billých myších bylo $\mathrm{v}$ průběhu března až prosince 1979 vyšetřeno 72 kusủ drobných volně žijících savců a ptáků. Odchyty byly prováděny $\mathrm{v}$ břeżnu, květnu, červnu a listopadu. Izolace $T$. gondii byla prováděna $\mathrm{z}$ mozku zvírat. U zviřat odchycených $\mathrm{v}$ březnu byla $T$. gondii izolována ve $21,7 \%$, u odchycených v květnu v $10,5 \%$, u odchycených v červenci $\mathrm{v} 18,7 \%$, u odchycených $\mathrm{v}$ listopadu v $18,6 \%$. Z celého souboru 72 kusů zvírat byla pozitivní izolace v $19,4 \%$. Původce byl prokázán u vrabce domácího (Passer domesticus) v 17,5\%, u vrabce polního (Passer montanus) v $25 \%$, u strnada obecného (Emberiza citrinella) ve $20 \%$, u myši domácí (Mus musculus) v $60 \%$, u myšice křovinné (Apodemus sylvaticus) ve $20 \%$. Původce nebyl prokázán u rehka zahradního (Phoenicurus ochruros), konipasa bílého (Motacilla alba), jiřičky obecné (Delichon urbica), zvonohlíka zahradního (Serinus serinus), stehlíka obecného (Carduelis carduelis). 


\section{Изоляџиснное определение Тохопласма гондии у мелких свободно обитающих млекопитающих и птиц}

Изоляционным определением токсоплазмы негативных белых мышей в ходе марта - декабря 1979 г. обследовались 72 свободно обитающее млекопитающее и птицы. Улавливание проводилось в марте, мае, июне и ноябре. Изоляция Токсоплазмы гондии проводилась из мозга животных. У животных, нойманных в марте, Токсоплазма гондии была изолирована в 21,7 \% случаев, у животных, пойманных в мае месяце, - в 10,5\%, в июне $18,7 \%$, в ноябре - в $18,6 \%$ случаев. Из 72 животных положительная изоляция Токсоплазмы гондии наблюдалась в 19,4 \%. Болезнетворный возбудитель был установлен у домового воробья (Passer domesticus) в 17,5 \%, у полевого воробья (Passer montanus) в $25 \%$, у обыкновенной овсянки (Emberiza citrinella) в $20 \%$, у домовой мыши (Mus musculus) в $60 \%$, у лесной мыши (Apodemus sylvaticus) в $20 \%$. Возбудитель не был установлен у обыкновенной горихвостки (Phoenicurus ochruros), у трясогузки (Motacilla alba), у городской ласточки (Delichon urbica), Serinus serinus, щегла (Carduelis carduelis).

\section{References}

ČATÁR, G.: Studies on toxoplasmosis as regards its natural focality in Slovakia. Folia parasitol., Praha, 19, 1972: 253-256.

EYLES, D. E. - GIBSON, E. L. - COLEMAN, N. - SMITH, C. S. - JUMBER, L. B. JONES, E. E.: The prevalence of toxoplasmosis in wild and domesticated animals of the Memphis region. Am. J. trop. Med. Hyg., 8, 1959: 505-510.

HASLETT, T. M. - SCHNEIDER, W. J.: Occurrence and attempted transmission of Toxoplasma gondii in European starlings (Sturnus vulgaris). J. Wildlife Dis., 14, 1978: 173-175.

ISTOMINA, L. B. - MJASNIKOV, J. - RYLCEVA, E. V.: Metod diffusionnoj precipitacii v agare pri izučenii toksoplazmoza u melkich lesnych mlekopitajuščich. Ž. Mikrobiol. Epidem. Immunobiol., 50, 1973: 127-129.

JÍRA, J. - ROSICKÝ, B. - BOZDĚCH, V.: Některé aspekty teorie přírodní ohniskovosti u toxoplazmózy. Folia parasitol., Praha, 12, 1965: 13-33.

ROSICKÝ, B. - JÍRA, J. - ŠEBEK, Z.: Toxoplazmové protilátky u drobných savců $\mathrm{z}$ hranice lesa v Krkonoších. Čs. Epidem. Mikrobiol. Imunol., 18, 1969: 290-294. 